\title{
Isolation of Histoplasma Capsulatum Var Farciminosum and other Co-Infecting Bacteria from Local Breeds of Horses with Characteristic Lesion of Epizootc Lymphangutis in Akaki and Kality Districts, Central Ethiopia
}

\author{
Kefyalew Mideksa ${ }^{1}$, Reta Tesfaye ${ }^{1}$, Asmelash Tassew ${ }^{2 *}$ \\ ${ }^{1}$ SPANA project, Addis Ababa University, College of Veterinary Medicine, Bishoftu, Ethiopia, P.O.Box: 34 \\ ${ }^{2}$ Raya University, College of Agriculture and Natural Resources; Department of Animal Science; P.O.Box: 92; \\ Maichew, Ethiopia
}

*Corresponding Author: Asmelash Tassew, Raya University, College of Agriculture and Natural Resources; Department of Animal Science; Maichew, Ethiopia. Email: asmelash21 @yahoo.com

\begin{abstract}
Across sectional study was carried out from November 2016 up to May 2017 in Bishoftu and Akaki towns in order to isolate Histoplasma capsulatum var farciminosum (HCF) and other co-infect bacteria from local breeds of horses with characteristic lesion of Epizootc lymphangutis. A questionnaire was also designed and administered to assess the socio- economic impact of the disease in the community. A total of 72 clinical specimens (pus) were collected aseptically using a purposive sampling technique. These specimens were examined under microscope to identify HCF. It was also cultured on Sabourad's Dextrose Agar media and various bacteriological culture media and selective media for isolation of fungus and bacteria respectively. Only (58.3\%) of mycelia growth was recorded and (98.6\%) indicated positivity under microscope using stain. Regarding the isolation of co-infect bacteria, Staphylococcus (88.8\%), Streptococcus (41.2 \%), Micrococcus (75\%), gram positive Bacilli (41.7\%), Corynebacterium ( 22.2\%), Aeromona (34.7\%), Proteus (20.8\%), Klebssiella (22.2\%), Pseudomonas (20.8\%) and E coli (6.8\%) were identified. The study animals were also classified as those which never get treatment and those horses taking therapy (topical iodide application) in the SPANA Clinics. The occurrences of co-infect bacteria was found greater in those horses which didn't take any therapy. But the treatment does not protect the emerging of new nodules and co-infect bacteria. Similarly, the study animals were grouped in to early, moderate and severe based on stage of the disease. The proportion of bacterial isolates was greater in those horses which were severely infected than those horses grouped in the moderate and early cases of the disease. The presence of co-infect bacteria were observed in both study area with some difference in proportion. The impact of the disease was assessed by asking various communities including users owners, traffic polices and workers from municipality whose their job related with urban hygiene and greener. The response of all respondents clearly indicated that the disease is causing lots of negative consequences in the community by reducing the income, performance and welfare of the animals. The current study revealed the presence of various bacterial species which may aggravate the disease and comprise the progress of treatment. As the impact of the disease is increasing in the societies, effective control measures like combined application of chemotherapy should be put in place.
\end{abstract}

Keywords: Akaki, Bacteria, Bishoftu, Epizootic lymphangiti, Histoplasm capsulatum var farciminosum, Horse, Isolation

\section{INTRODUCTION}

In Ethiopia, the transportation infrastructure is at its lower stage particularly in the rural areas (Birhanu et al., 2014). As a result, most of the transportation activities are performed by the use of Equines. Besides, in the northern and north-western part of the country, equines have also been used for ploughing activities showing their contribution in crop production. In some part of the country they are used as food source (Ameni et al., 2006; EARO, 1999; SPANA,
2006). Despite their uses, equines suffer from many diseases, among which Equine histoplasmosis (EH) or Epizootic lymphangitis (EL) is one of the nastiest chronic fungal disease seen mainly in equids. It is caused by Histoplasma capsulatum var. farciminosum a thermally dimorphic fungus. particularly in Africa, Middle East and Asia. Epizootic lmphangitis is called a 'fat leg' because it is known by swelling of legs. In Ethiopia EL is known as 'Biche' in Afan Oromo and 'Nidifit' in 
Isolation of Histoplasma Capsulatum Var Farciminosum and other Co-Infecting Bacteria from Local Breeds of Horses with Characteristic Lesion of Epizootc Lymphangutis in Akaki and Kality Districts, Central Ethiopia

Ameharic (Ameni and Tilahun, 2003). The disease is more common in the tropics and subtropics and is endemic in north, east and west Africa, and some parts of Asia, including some countries bordering the Mediterranean Sea, India, Pakistan and Japan (CSFPH, 2009). The disease is common in Ethiopia, especially in cart horses, affecting an average of $18.8 \%$ of horses in warm, humid areas between 1500 and 2300 metres above sea level (Ameni, 2006; Ameni \& Terefe, 2004).

Epizootic lymphangitis is a chronic contagious rampant and debilitating fungal disease mainly of horses but also affects mules and donkeys. As the reports indicated that $90 \%$ of the cases were observed in horses followed by mules but the disease is less common in donkeys (Awad, 1960; Carter and Chegappa,1991). The rate of infection varies among different geographical areas (Al-Ani and Ali- Delaim, 1986).

Due to this disease the horse become debilitated and develop secondary infection and quit often they are abounded and seen on the road sides without any feed and water (Ameni, 2006a, Getchew et al., 2007, Tobianse et al., 2016, SPANA, 2006).

Epizootic lymphangitis has major socio economic impact as a result of death of affected horses and decline in the net profit per day due to reduced working performance of affected horses (Stephanie, 2014, Jagema and Jarso, 2016). (Birhan, et al., 2014; Meles et al., 2008). Because the passengers never use a horse with EL as healthy animals for transport (Pal, 2007). According to participatory studies conducted to prioritize diseases of working equine in Ethiopia, EL was ranked as the most important disease (Stephanie, 2014, Jagema and Jarso, 2016). Other study indicated that attentions given for thus species of animals was less because of horses are not providers of meat and milk at least in Ethiopia so that is misconception of the owners about the hardiness and tolerance of equines against adverse effects including diseases (Feseha, 1993).

The diagnosis of EL is based on characteristic clinical signs and laboratory confirmation through demonstration of the organism in smear. The organism has two forms; mycelial /saprophitic form is found in nature in the soil and the yeast form is found in tissues (Pal, 2007). Like other lesions, horse wounds have high risk of becoming infected due to

ARC Journal of Animal and Veterinary Sciences environmental contamination. Infected wounds have high chance to harbor diverse population of microorganisms that cause failure to treatment responses in this disease. Healing of equine wounds particularly in the limbs is difficult due to hydrostatic factors and exposure to environmental contaminant which can lead to infection and delay healing (Tobianse et al., 2016). Bacillus, Aeromonus, Klebsiela, Staphylococcus, Micrococcus and Rhodococcus bacterial contaminants were reported in and on EL lesions (Hadush et al., 2008).

Regarding the treatment, none of the recommended anti-fungal drugs for the treatment of EL are available in Ethiopia veterinary clinics because of the high cost of the drug (SPANA, 2006, Getachew et al., 2007). So the fate of severely affected horses and mules or equines in general is to be left without proper treatment as they can be seen in the fields and road sides without any feed and water (Ameni, 2006a; SPANA, 2006; Getachew et al., 2007). Once the infected animals become abundaned on the road side, they become source of infection to other susceptible animals and their welfare is also abused. This study was aimed to find some major bacterial contaminants in EL lesions that may contribute to the failure of effective treatment of EL. Co-infect bacteria associated with EL had not been studied and there has no report from current study area. So the objectives of this research were:

$>$ Identification of co-infect bacterial from epizootic lymphangitis lesion in horses.

$>$ Isolation of Histoplasma capsulatum var farcimnosum from EL infected horses

$>$ Assessment of the consequences of Epizooitic lymphangitis in the community

\section{MATERIALS AND MeTHOdS}

\subsection{Description of Study Area}

The study was conducted in Bishoftu and Akaki towns Bishftu is located in Adea district, Oromia regional state, Ethiopia. It is located at $45 \mathrm{~km}$ away from the capital city, Addis Ababa. Bishoftu town is found at 1900 meter above sea level and receiving an annual rainfall of $1115 \mathrm{~mm}$ with two rainy season: March to May (short rainy season) June to September (main rainy season). The annual average maximum and minimum temperature are $10^{\circ} \mathrm{c}$ and $8.5^{\circ} \mathrm{c}$ respectively with relative humidity of $61.3 \%$ (NMSA, 2003). 
Akaki is one of the sub cities in Addis Ababa. It is located at an altitude of 2120 meter above sea level with annual rain fall of $1200 \mathrm{~mm}$ and annual average maximum and minimum temperature of $20^{\circ} \mathrm{C}$ and $18^{\circ} \mathrm{c}$ respectively. The area experiences bimodal rainfall pattern with short rainy season from March to May and the long rainy season from June to September (NMSA, 2003). The report shows that 22,676 donkeys, 6,136 horses, and 2,015 mules are found in this town (Dessalegn et al.,2016)

\subsection{Study Animals}

Horses of local breed with characteristic EL lesion were included in this study. Fifty six from Bishoftu and sixten from Akaki were included.

\subsection{Study Methods}

\section{Clinical Examination of the Animals}

Physical and systematic clinical examination of horses was done to identify animals with a clinical signs of EL. During the examination, owners name and address, animal identification, observed clinical signs, body parts involved, number of topical nodules or ulcers of the selected horses were recorded.

The identified horses were categorized into three different groups based on the stages of disease. Stages of the disease were determined by level of cording, the number of sites and limbs involved and diameter of lesion and number of palpable nodules and lymph nodes. Criteria that were used to categorize the three stages are indicated in Table 3( Getachew, 2007).

\section{Handling Animals During Sampling}

Before sampling, animals were well restrained using nose twitch and in aggressive horses sedatives were used (Hulme, 2002).

\subsection{Sample Collection, Processing and Examining}

Pus samples were collected from un-ruptured palpable nodules using sterile syringe and needle after the nodules were washed with soap and water, shaved, and disinfected with alcohol. The aspirated content of the nodules were used for the preparation of smears for microscopic examination and cultured on different media (Getachew et al., 2007). Media were prepared according to the rules prescribed on the bottle container (Annex 2). Media were weighed, dissolved using heat and shakers, autoclaved at $121^{\circ} \mathrm{C}$ for sterilizing and cool in water bath at $50^{\circ} \mathrm{C}$ and dispensed in to petridishes and wait to cool and for blood agar enriched with $7 \%$ defibrinated sheep blood as well as procain penicillin $\mathrm{G} 6 \times 10^{6} \mathrm{IU}$ for SAD agar preparation. Once the medium were prepared and ready to use aseptically collected pus sample was inoculated or stricken under laminar air flow on different plates to avoid contaminants on sterile media and incubated in incubator at $37^{\circ} \mathrm{C}$ in inverted position for yeast growth and at room temprature for mycelial growth. The samples were cultured on nutrient agar media for less fastidious organism growth and on blood agar (Oxoid, $\mathrm{U}$ ) for fastidious bacteria isolate and to check heamolsis. Macconkey agar (Oxoid UK), was used for isolation of gram negative bacteria and the isolates were further sub cultured on Eosin Methylene blue (EMB) and Xylose Lysine Deoxycholate (XLD) agar. All agar plates were incubated aerobically at $37^{\circ} \mathrm{C}$ for 24to 48 hours and then bacterial colonies were identified. Staphylococcus and Aeromas were isolated from Manitol salt agar (Oxoid UK),Streptococcus isolated from Eduward media (Oxoid UK), Escherchia coli isolated from Eosin Methyl Blue (Oxoid UK), Klebsiella and Proteus isolated from XLD agar. The colony were examined macroscopically for morphology and by further stain. The aspirated pus samples were also cultured on two Sabouradus Dextrose Agar (SDA) impregnated with Fortified procain penicillin $G$ to identify the mycelia form incubated at room temperature and yeast form incubated at $37^{\circ} \mathrm{C}$.The inoculated media are kept at $25^{\circ} \mathrm{C}$ for $2-8$ weeks as it has slow growth in case of fugal mycelial agent. The direct smears of same sample was fixed with heat, stained with gram stain for the identification of the yeast form of HCF. Examination were made using $40 \mathrm{x}$ magnification followed by oil immersion at $100 x$ magnification until the fungus and bacteria was demonstrated in the clinical specimens as described by Carter,(1991), Getechew et al.,(2007) and Asfaw et al., (2012,). Annex 4. So isolation and identification of bacterial contaminants and the fungus causative agent was done by smear, colony characteristics and use of selective media.

\subsection{Study Design and Sampling Method}

The study design was cross- sectional type. Purposive sampling method was used to select 72 horses with typical EL lesions. Infected horses were grouped in to three categories (Early, Moderate and sever) based on the 
Isolation of Histoplasma Capsulatum Var Farciminosum and other Co-Infecting Bacteria from Local Breeds of Horses with Characteristic Lesion of Epizootc Lymphangutis in Akaki and Kality Districts, Central Ethiopia

severity of the disease. Each of these categories were divided in to two sub groups based on whether they were taking treatment or not(new case join SPANA clinic and others follow treatment).

\subsection{Questionnaire Survey}

\section{Ethical Clearance}

Ethical clearance certificate for this research was obtained from Addis Ababa University, College of Veterinary Medicine to conduct questionnaire survey and for sample collection from study horses and attached at end of this paper.

Structured semi closed questionnaire was developed and delivered to respondents to collect information related to the impacts of EL. Before the interview, the aim of the study were briefed for the respondents and were asked for their voluntariness. Accordingly, 100 respondents of different groups of key stalk holder including horse owners, community members/users of cart horse for transportation, traffic police man, and person from municipality working on town sanitation and hygiene were interviewed. The base line for selection of respondents were nearby to uses of horses in case of users and owner while disease predispose horses on main roads for the case of traffic police man and urban greener and hygiene keepers.

\subsection{Data Management and Analysis}

The collected data related to the findings were coded and entered in to MS excel spread sheet. Statistical analysis was performed using SPSS version 20. Descriptive statistics including frequencies percentages, graph were used to summarise the results.

\section{Results}

In this study,72 horses with characteristic lesions of EL were sampled for identification of the causative agent of EL and associated coinfect bacteria involved. Direct gram stained smears of the contents of pyogranulomatous skin nodules revealed the presence of EL causing organism, HCF yeast form, in 71 cases from 72 samples and 10 bacterial genera were isolated based on gram stain of colonies from cultured samples and also colonies characteristics on selective media.

\subsection{Microscopic Examination of Yeast Under Gram Stain and Macroscopic Appearance of Mycelia Colony of HCF on SDA Media}

Out of 72 examined samples $71(98.6 \%)$ of Histoplasma capsulatum var farciminosum yeast was identified by direct microscopic examination whereas $42(58.9 \%)$ of mycelia growth was observed by culturing on SDA enriched with $2.5 \%$ glycerol media. Unfortunately the yeast form negative to growth within 6weeks .

\subsection{Bacterial Isolates from Horses with EL Nodules with Pus}

Different bacterial genera including gram positive bacilli and gram negative bacilli such as Aeromonus, Klebsiella, proteus, pseudomonas and $E$ coli were isolated. Besides,gram positive cocci such as Staphylococcus, Micrococcus, Streptococcus and Corynebacterim were isolated from different stages of EL lesions. Mixed infection was common and at least one bacterial genera was identified from all samples examined. The common bacteria isolated from EL lesions were Staphylococcus species 64 (88.8\%) and Micrococcus 54 (75\%). Table 1

Table1. Bacteria isolated from pus of horses with EL lesions $(n=72)$

\begin{tabular}{|l|l|}
\hline Bacterial isolates & Number $\mathbf{( \% )}$ \\
\hline Staphylococcus & $64(88.8)$ \\
\hline Micrococcus & $54(75)$ \\
\hline Streptococcus & $30(41.1)$ \\
\hline Corynebacterium & $16(22.2)$ \\
\hline Aeromonus & $25(34.7)$ \\
\hline Klebsiella & $16(22.2)$ \\
\hline Proteus & $15(20.7)$ \\
\hline Pseudomonas & $15(20.8)$ \\
\hline E coli & $5(6.8)$ \\
\hline Other gram positive bacilli & $30(41.7)$ \\
\hline
\end{tabular}


Isolation of Histoplasma Capsulatum Var Farciminosum and other Co-Infecting Bacteria from Local Breeds of Horses with Characteristic Lesion of Epizootc Lymphangutis in Akaki and Kality Districts, Central Ethiopia

\subsection{Bacterial Isolates from Horses Under Treatment with Topical Iodine and New EL Cases without Treatment}

Pus samples were collected from 43 horses which were under treatment with topical $4 \%$ iodine tincture and 29 new cases. Different bacteria were identified both from horses under treatment and non-treated horses. The

Table2. Bacterial isolation rate from horses under treatment and without treatment

\begin{tabular}{|l|l|l|}
\hline $\begin{array}{l}\text { Isolated bacterial } \\
\text { contaminants }\end{array}$ & $\begin{array}{l}\text { Frequency of isolates under } \\
\text { treatment in } \mathbf{\%})(\mathbf{n = 4 3})\end{array}$ & $\begin{array}{l}\text { Frequency of isolates in horses without } \\
\text { treatment in }(\boldsymbol{\%})(\mathbf{n}=\mathbf{2 9})\end{array}$ \\
\hline Staphylococcus & $35(81 \%)$ & $27(96.4 \%)$ \\
\hline Micrococcus & $30(69.7 \%)$ & $24(87.7 \%)$ \\
\hline Streptococcus & $22(51.1 \%)$ & $8(28.6 \%)$ \\
\hline Corynebacterium & $10(22.4 \%)$ & $6(21.4 \%)$ \\
\hline Aeromonus & $15(36.3 \%)$ & $10(35.7 \%)$ \\
\hline Klebsiella & $7(16.2 \%)$ & $8(28.6 \%)$ \\
\hline Proteus & $11(27.2 \%)$ & $3(10.7 \%)$ \\
\hline Pseudomonas & $10(22.6 \%)$ & $5(17.8 \%)$ \\
\hline E. coli & $1(2.3 \%)$ & $4(13.8 \%)$ \\
\hline Other gram positive bacilli & $15(38 \%)$ & $13(46.4 \%)$ \\
\hline
\end{tabular}

3.4. Bacterial Isolates from Horses with Different Stages of EL Cases

The study animals were categorized in to early, moderate and sever cases of EL. Accordingly 32,22 and 18 horses were categorized as early, moderate and sever cases respectively. It was found that high proportion of different bacterial

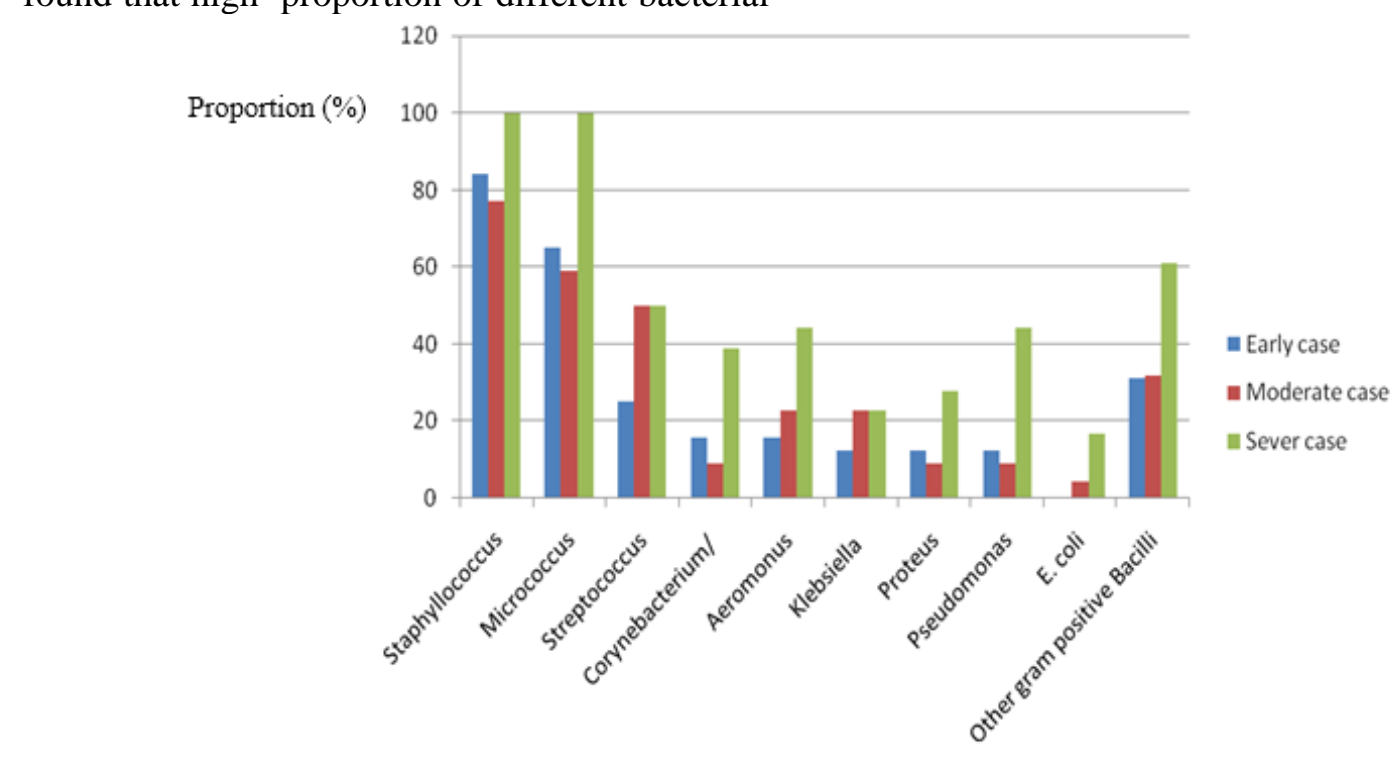

Bacterial isolates occurrence of Staphylococcus, Micrococcus, Klebsiella and E. coli were relatively higher in horses without treatment while the occurrences of Streptococcus and Proteus were relatively higher in horses under treatment. The occurrences of other bacterial isolates were almost similar as indicated in Table 2 isolates were frequently identified in severe cases as compared to moderate and early cases. The frequency in percentage of bacterial isolates in relation to the severity of EL cases are indicated on figure 20 and presented on graph using bars. Figure 1.

Figure1. Bacterial isolated from pus samples of different stages of EL infected horses explained using bars in percentage.

\subsection{Area Based Occurrence of Isolated Bacterial Contaminant from EL Lesion}

From 16 samples collected and examined from Akaki, Staphylococcus was identified in 15 $(93.7 \%$ ) samples. This bacteria was also ARC Journal of Animal and Veterinary Sciences isolated from $49(87.5 \%)$ of samples collected from Bishoftu town and were most common pathogens. The result of this study indicated the existence of all bacterial isolates in the study areas. Table 3 
Isolation of Histoplasma Capsulatum Var Farciminosum and other Co-Infecting Bacteria from Local Breeds of Horses with Characteristic Lesion of Epizootc Lymphangutis in Akaki and Kality Districts, Central Ethiopia

Table3. Area based occurrence of isolated bacterial contaminant from EL lesion

\begin{tabular}{|l|l|l|}
\hline \multirow{2}{*}{ Bacterial contaminants } & Proportion in different distinct \\
\cline { 2 - 3 } & Bishoftu town (n=56) & Akaki town ( n=16) \\
\hline Staphylococcus & $49(87.5 \%)$ & $15(93.7 \%)$ \\
\hline Micrococcus & $43(76.7 \%)$ & $11(68.7 \%)$ \\
\hline Streptococcus & $18(32.1 \%)$ & $12(75 \%)$ \\
\hline Corynebacterium & $11(19.5 \%)$ & $5(32.1 \%)$ \\
\hline Aeromonus & $18(32.1 \%)$ & $7(16 \%)$ \\
\hline Klebsiella & $11(19.6 \%)$ & $5(32.1 \%)$ \\
\hline Proteus & $10(17.8 \%)$ & $5(32.1 \%)$ \\
\hline pseudomonas & $11(19.6 \%)$ & $4(25 \%)$ \\
\hline E coli & $4(71.7 \%)$ & $1(6.2 \%)$ \\
\hline Other gram positive bacilli & $24(42.8 \%)$ & $6(37.5 \%)$ \\
\hline
\end{tabular}

3.6. Questioner Survey on the Effect of horses, it may be owners focused on income Epizootic Lymphangitis among Different Groups of Community

Different community groups (owners, users of cart horse for transportation, traffic polices and persons from municipality) were interviewed for their perception on the effect of the disease within the community. In this questionnaire survey, all the respondents indicated that the performance and income generated adversely affected due to EL. Except the owners, all respondents in other group replied that the welfare of horses is compromised in horses affected with EL because the owner perception rather welfare of infected horse and they think that the horse get feed were enough. Incomes collected by those animals were reduced that is because user haven 't showed interest to use such animals due to smelling, flies, weak in walking and other reasons. Besides, almost all respondents agree that whenever infected animals are abounded they may cause environmental contamination, act as a source of infection for other horses and cause for traffic jam which may results in car accident. The observed cases of EL infected horse indicated the fact. (Table 4)

about the welfare compromise of infected

Table4. Respondent Reply Result Related to the Effect of the Disease within the Community

\begin{tabular}{|c|c|c|c|c|c|c|c|c|c|}
\hline \multirow[b]{3}{*}{ Respondents } & \multicolumn{9}{|c|}{ Respondents feeling and idea to the question raised about EL effect. } \\
\hline & \multicolumn{3}{|c|}{$\begin{array}{l}\text { Effect of disease } \\
\text { Reduced in }(\%)\end{array}$} & \multicolumn{3}{|c|}{$\begin{array}{l}\text { Fate of severely infected } \\
\text { horses abandoned to }(\%)\end{array}$} & \multicolumn{3}{|c|}{$\begin{array}{l}\text { The consequences of severely } \\
\text { infected horse by EL abounded } \\
\text { and cause for (\%) }\end{array}$} \\
\hline & 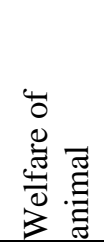 & $\underset{\Xi}{\Xi}$ & 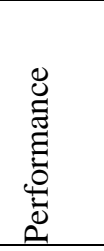 & 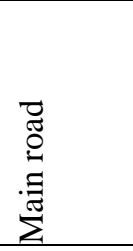 & $\stackrel{\vec{\Omega}}{a}$ & 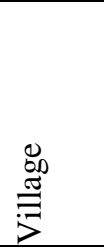 & 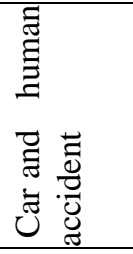 & 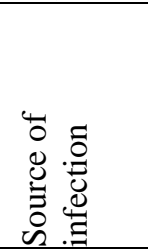 & 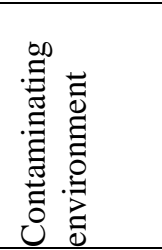 \\
\hline Owner $(\mathrm{n}=40)$ & $\begin{array}{l}18 \\
(45)\end{array}$ & $\begin{array}{l}40 \\
(100)\end{array}$ & $\begin{array}{l}40 \\
(100)\end{array}$ & $40(100)$ & $31(77.6)$ & $36(90)$ & $36(90)$ & $39(97.5)$ & $17(42.5)$ \\
\hline Users $(n=25)$ & $\begin{array}{l}25 \\
(100)\end{array}$ & $\begin{array}{l}25 \\
(100)\end{array}$ & $\begin{array}{l}25 \\
(100)\end{array}$ & $25(100)$ & $22(88)$ & $24(96)$ & $25(100)$ & $25(100)$ & $17(68)$ \\
\hline $\begin{array}{l}\text { Traffic polices } \\
(\mathrm{n}=20)\end{array}$ & $\begin{array}{l}20 \\
(100)\end{array}$ & $\begin{array}{l}20 \\
(100)\end{array}$ & $\begin{array}{l}20 \\
(100)\end{array}$ & $15(75)$ & $6(30)$ & $10(50)$ & $20(100)$ & $20(100)$ & $20(100)$ \\
\hline $\begin{array}{l}\text { Person from } \\
\text { municipality } \\
(\mathrm{n}=15)\end{array}$ & $\begin{array}{l}15 \\
(100)\end{array}$ & $\begin{array}{l}15 \\
(100)\end{array}$ & $\begin{array}{l}15 \\
(100)\end{array}$ & $15(100)$ & $9(60)$ & 14(93) & $15(100)$ & $15(100)$ & $14(93)$ \\
\hline
\end{tabular}

\section{DISCUSSION}

Among 72 examined pus samples,71 $98.6 \%$ ) were found to be positive for Histoplasma capsulatum var farciminosum yeast up on direct microscopic examination using gram stain techniques and $42(58.9 \%)$ of the mycelia form of the fungus was grown on mycobiotic agar
(SDA) enriched with 2.5\% glycerol and addition of antibiotics. Mycelia form grown in suitable temperature and media (Ali Ani, 1999) penicillin $\mathrm{G}\left(6 \times 10^{6}\right.$ unit/liter) were used instead of chloranphenicol to avoid the contaminant bacterial (Selim et al., 1985; Radostis et al., 2007). The growth of mycelia colony was slow and the Colonies appeared as dry, granular, 
Isolation of Histoplasma Capsulatum Var Farciminosum and other Co-Infecting Bacteria from Local Breeds of Horses with Characteristic Lesion of Epizootc Lymphangutis in Akaki and Kality Districts, Central Ethiopia

wrinkled, cerebriform colonies, convoluted grey white and become yellow to dark brown similar to study before (Awad, 1960; Ali-Ani 1999; Ameni and Siyoum, 2002; OIE, 2008). The prevalence of this disease in this study is more than study conducted Before, $10.4 \%$ (Endebu and Rogeer, 2004) this indicated that there is infection of horses by this disease which support present study. However the difference in prevalence might be due to purposive sampling technique were used, only infected horses that clinically showed the using of EL were include that was suggestive for the disease.

The current study indicated that some different bacterial genera were isolated from all samples collected from lesions of EL. The bacterial genera isolated include: gram positive bacilli and gram negative bacilli including Aeromonus, Klebsiella, proteus, pseudomonas, Corynebacterium and E. coli from bacilli group and Staphylococcus, Micrococcus, Streptococcus and from cocci group from samples of different stages of EL lesions. This finding is closely comparable with (Hadush et al.,2014) who reported majority of currently identified bacteria from EL lesions. The difference might be the difference in wound type which the samples were collected. Horse wounds have a high risk of becoming infected due to their environment. It is well documented that infected wounds harbor diverse populations of micro organisms that can be difficult to identify and fail to respond to antibiotic treatment, resulting in chronic non-healing wounds (Westgate et al., 2011; Nagoba B. et al, 2013; Carnwath et al., 2014).

The most commonly isolated bacteria from the EL lesions were Staphylococcus species (64, $88.8 \%$ ) and Micrococcus $(54,75 \%)$ followed by Streptococcus, other gram positive bacilli (30, 41.7\%) and Aeromonas (25, 37.7\%). The remaining bacteria were relatively identified less frequently. E. coli being the least frequent. The dominance of Staphylococcus, Micrococcus and Strepotococcus may be due the fact that those bacteria are commonly found as skin flora of animals where easily to invade the infected skin tissues. But the rest of isolated bacterial found in environment and mud area or in aquarium (Aeromonas) where it may get probability of invading affected skin of animals. So, in severe cases more prominent due to the lesion or wounded skin part increased. In line with this, several reports indicated that Staphylococcus was the most commonly isolated genus in wounds and skin sample (Theoretic, 2012; Carnwath et al.,2014; Tobianse et al., 2016). Other study also supported that the most implicated bacteria in lymphangitis and cellulitis in horse are coagulase positive and negative Saphylococcus species, Streptococcus, gram negative aerobic or an aerobic bacteria. However it was common isolates with other study, it prevalence in this study was high, may be due to directly take from pus form nodule. The current finding agrees with the positivity with Wilson (2001) and Westgate et al.; 2011 finding in which Pseudomonas were the most predominantly isolated bacterial species from equine wound and skin samples respectively. The presence of gram negative bacteria including E. coli, Proteus Vugaris and $P$. aeroginosa in wounds aggravate the severity of infection besides to other criteria and cause for the delaying of wound healing (Bessa et al., 2015; Nagoba et al., 2013). So wound management in equine patient can be very difficult due to bacterial infection indicated that using anti microbial agents is also very important (James, 2014).

The proportion of bacterial contaminants increased with the severity of the stages of disease because it may be due to severity of disease, the chronic nature of disease and their availability in different environments. So bacteria have get chance to invade the lesion easily exposed wounds to co-infect Bacterial complicated infection and invaded EL lesions caused for bad smelling. The study supported that in advanced cases, the nodules and ulcers may have unpleasant odor in advanced case (Ameni, 2007) and welling of the lymphatic vessel is due to bacterial complication restrict lymph vessel. From this angle the organisms may be disseminated hematogenously, even from the smallest abscess could ability to aggravating the disease. These indicated that the presence of bacterial contaminates in lesions of EL infected horses.

Questionnaire survey was also designed in order to find the perception of respondent the importance of epizootic lymphangitis due to the effects of the disease on the horse and its impact on human livelihoods. According to response of different groups of community, the negative effect of epizootic lymphangitis is multidirectional. Though the magnitude of the problem is difficult to precisely describe, EL is known to lower the daily income of household, 
Isolation of Histoplasma Capsulatum Var Farciminosum and other Co-Infecting Bacteria from Local Breeds of Horses with Characteristic Lesion of Epizootc Lymphangutis in Akaki and Kality Districts, Central Ethiopia

critically decreases the working performance and welfare of horses. According to respondent replay in this study all respondents indicated that EL adversely affect the performance of horses and the income generated using infected horses. The reduction income might arise from the reduction in working ability and refusal of passengers the working cart horses with EL and due to the death of severely affected animals. This may have a direct impact upon the livelihoods of owners and their dependent family members. In line with this all groups of respondent except the owners agree that EL compromises the welfare of animals. From the owner groups only $45 \%$ of them recognized the welfare problem in EL infected horses it may indicated that horse with EL to be work and in sever case abandoned. Study supported this horse, with EL continued to worked and in advanced cases, horses were abandoned due to in effective or unavailable treatment (Stephanie, 2014; Scantlebery et al., 2015). According to respondents view horses with severe case of EL, $100 \%$ said that stand on middle of main road, $48.2 \%$ abandoned to river area and $82.2 \%$ of respondents said that stayed in the village. Study also indicated that the horses become debilitated and develop secondary infection and quit often they are abounded and seen on the road (Stephanie, 2014). The consequence of the abandoned in different place were also accessed and investigated in this study. Accordingly different respondents replied that in average $97.7 \%$ of respondents replied that potential causes of cars and human accident, $93.7 \%$ of respondents replied that resulted in source of infection and $76.2 \%$ of respondents replied that severely affected and abounded horses are contaminating the environments because of bad smelling. So early checking and follow up is important before come to advanced.

\section{ACKNOWLEDGEMENTS}

The authors are thankful to College of Veterinary Medicine, Addis Ababa University and SPANA Project for their unreserved support during the study.

\section{REFERENCES}

[1] Ali-Ani, F.K. 1999. Epizootic lymphangit in horses: a review of the literature. Rev.Sci.Tech, 18:691-699.

[2] Ali-Ani, FK.and Ali-Delaimi, K.A. 1986. Epizootic Lymphangitis in horses: clinical epidemology and hematological studies. Pak.Vet. J, 6: 96-100.
[3] Ali-Ani, F.K., Ali, A.H. and Banna, H.B. (1999): Histoplasma farciminosum infection of horses in Iraq.Veterinaski Arhiv, 68:101-107.

[4] Ameni, G. and Siyoum, F. 2002. Study on Epizootic lymphangitis in cart horses in Ethiopia J.vet., Sci, 3:135-139.

[5] Ameni, G. 2006a. Epidemiology of equine histoplasmosis in cart horses in Ethiopa. Vet. J, 172: 160-165.

[6] Ameni, G. and Terefe, W. 2004. A crosssectional study of epizootic lymphangitis in cart-mules in western Ethiopia. Preventive Vet. Med.,66: 93-99.

[7] Ameni, G. and Tilahun, G. 2003. Preliminary laboratory and field trials on the effect of Endod (Phytolacca dodecandra) on epzootic ly mphangitis.Bull. Anim. Hlth. Prod. Afr,51:153160.

[8] Awad, F.I.1960. Studies on epizootic lymphangitis in the Sudan. J. Comp. Path, 70: 457.

[9] Ameni, G.,Terefe, W. and Hailu, A. 2006. Histofarcin test for the diagnosis of epizootic lymphanigitis in Ethiopia: development, optimisation and validation in the field. Veterinary J.,171: 358-362.

[10] Bessa L J, Fazii P, et al 2015. Bacterial isolates from infected wounds and their antibiotic susceptibility pattern: some remarks about wound infection. International Wound Journal;12: 47-52.

[11] Carter, G.R. and Chengappa, M.M. 1991.Essentials of Veterinary Bacteriology and Mycology. 4th Edition, Lea and Febiger, Philadelphia,:Pp. 261-271.

[12] Carnwath R, Graham EM, Reynoldsk, Pollock PJ (2014): The antimicrobial activity of honey against common equine wound isolates. Vet. J., 199: 110-114.

[13] CSFPH (2009): Centeral Food Safety and public health.

[14] Dessalegn, G., Berhan, T. Gebreyohannes, B. 2016. Study of Reproductive and Production Performance of Cross Breed Dairy Cattle under Smallholders Management System in Bishoftu and Akaki Town. Int. J. Adv.Res. Biol. Sci. 3(2): 151-157.

[15] Endebu, B. and Roger, F. 2003. Comparative studies on the occurrence and distribution of epizootic lymphangitis and ulcerative lymphangitis in Ethiopia. Intl J App Res Vet Med. 3: 1-5.

[16] EARO 1999. National Animal Heath Research Program strategy Document; Bureau of Agricultural and National Resource Organization (BANRO), Addis Ababa, Ethiopia. 
Isolation of Histoplasma Capsulatum Var Farciminosum and other Co-Infecting Bacteria from Local Breeds of Horses with Characteristic Lesion of Epizootc Lymphangutis in Akaki and Kality Districts, Central Ethiopia

[17] Edward B. (2005): Black's veterinary dictionary. 21 $1^{\text {st }}$ Ed. A \& C Black Publishers Limited. 38 Soho Square, London. Pp.: 430

[18] Feseha, G. 1993. Use of Equines in Ethiopia. In: Proceedings of the Fourth National Livestock Improvement Conference. Addis Ababa, IAR, Ethiopia. pp 51-57.

[19] Getachew, A., Endebu, B., Gebreab, F., Jones, K., Akililu, N., Zerfu, A. and Mideksa, K. 2007. Treatment of epizoootic lymphangitis in cart horses through participatory method.

[20] Hadush, B., Ameni. G, Medhin, G. 2008. Equine histoplasmosis: treatment trial in cart horses in Central Ethiopia. Trop Anim Health Prod. 40:407-411.

[21] Hadush B., Biratu D., Taddele H., Tesfaye D., \& Ameni G. 2014. Bacterial contaminants isolated from lesions of equine histoplasmosis in cart horses of Mekelle town, northern Ethiopia. Revue Méd. Vet.,165: 25-30

[22] Hulme J. 2002. SPANA guids to animal care part I pp 2-8

[23] James A. 2014. Management of severely infected wounds in equine patient. Johnson, P., Howden, B. and Bennett, C. (2006): Staphylococcus aureus: a guide for the perplexed. Medical Journal of Australia, 184: 374-375.

[24] Jagema, T. and Jarso, D. 2016. Study on Epidemiology and Socioeconomic Impact of Epizootic Lymphangitis in Carthorses in Southwestern Shoa.

[25] Meles, B. 2008. Study on prevalence and socioeconomic impact of Equine Histoplasmosis in carthorses in Mekelle town. DVM thesis, Faculty of Veterinary Medicine, University of Mekelle, Ethiopia.

[26] NMSA, 2003. National Meteorological Service Agency, Addis Ababa, Ethiopia.

[27] Nagoba, B, Selkar, S, Wadher B. 2013. Acetic acid treatment of pseudomonal wound infection. A review infection. Public health. 6: $410-415$.
[28] OIE 2008. Manual of Standards for Diagnostic Test and Vaccines. Office International Des Epizooties. Paris, France, Pp. 852-857.

[29] Pal M. 2007. Veterinary and Medical Mycology. First Edition

[30] Radostits, O.M., Gay, C.C., Hinchcliff, K.W. 2007. Constable PD. Veterinary Medicine. $10^{\text {th }}$ Edition, Bailliere Tindall, London, PP 14781479.

[31] Scantlebury, C.E.,, Zerfu, A., Pinchbeck, G.P., Reed, K., Gebreab, F., Aklilu, N., Mideksa, K., Christley, R. 2015. Participatory appraisal of the impact of epizootic lymphangitis in Ethiopia.

[32] Selim, S.A, Soliman R, Osman K, Padhye A.A, and Ajello L. 1985. Studies on histoplasmosis farciminosi (epizootic lymphangitis) in Egypt. Isolation of Histoplasma farciminosum from cases of histoplasmosis farciminosi in horses and its morphological characteristics. Eur $\mathrm{J}$ Epidemiol; 1: 84-89.

[33] SPANA 2006. Consultant Document. The Horse Health and Welfare Project in Ethiopia: Joint Project between SPANA and Addis Ababa University, Debre Zeit, Ethiopia, 1-20 (Unpublished).

[34] Stephanie, L. 2014. Epizootic lymphangitis a working equids disease.

[35] Tobianse, O., Eile, B., Christina, H. and Alejdra, V. 2016. Fighting off wound pathogen in horse with honey bee lactic acid bacteria.

[36] Theoret, C. Wilmink, J. 2012. Aberrant Wound healing in the horses naturally occurring conditions reminiscent .wound repair regime. 21:365-371.

[37] Westgate, S.J., Percival, S.L., Knottenbelt, D.C., Clegg, P.D., Cochrane, C.A. 2011. Microbiology of equine wounds evidence of bacterial biofilm.

[38] White, S. 2005. Equine bacterial and fungal diseases A diagnostic and therapeutic update Tech equine pract, pp.302-310

[39] Wilson, W. 2001. Rational selection of antimicrobial for use in horse proceeding of the 47th Annual convention of America association equine practitioner pp 75-93.

Citation: Kefyalew Mideksa, Reta Tesfaye, Asmelash Tassew. Isolation of Histoplasma Capsulatum Var Farciminosum and other Co-Infecting Bacteria from Local Breeds of Horses with Characteristic Lesion of Epizootc Lymphangutis in Akaki and Kality Districts, Central Ethiopia. ARC Journal of Animal and Veterinary Sciences. 2019; 5(1):15-23. doi: dx.doi.org/10.20431/2455-2518.0501003.

Copyright: (c) 2019 Authors. This is an open-access article distributed under the terms of the Creative Commons Attribution License, which permits unrestricted use, distribution, and reproduction in any medium, provided the original author and source are credited. 